\title{
PENGARUH TANAMAN SELA SORGUM MANIS TERHADAP PERTUMBUHAN TANAMAN KARET BELUM MENGHASILKAN
}

\author{
(Effect of Sweet Sorghum Intercrops on The Growth of Immature Rubber Plant)
}

\author{
SAHURI
}

Balai Penelitian Sembawa, Pusat Penelitian Karet

Jl. Raya Palembang-P. Balai Km 29, PO BOX: 1127, Palembang 30001

Email: sahuri_agr@ymail.com

\begin{abstract}
The Land between row of immature rubber period has a potential to produce sweet sorghum. This sorghum is one of high value commodities for food and energy security due to its wide adaptation. The objective of this research were to study the effect of rubber+sorghum intercropping system on the growth of immature rubber trees and to study some agronomic parameters of sorghum and production of sweet sorghum as rubber intercrops. The experiment was conducted at the Sembawa Research Station from June to October 2013. The experiment was carried out as a single factori using Randomized Block Design with three replications. The treatment were 3 varieties of sorghum i.e: Pahat, Kawali and Mandau. Observation of rubber trees was conducted using simple random sampling method, comparing the rubber trees growth of sorghum intercropping system with the rubber trees growth of monoculture system. The results showed that sorghum had a positive effect on the growth of rubber tree IRR 118. Furthermore, fresh stem weight (37.11 t/ha), juice yield (1.80 t/ha), and grains yield (2.69 t/ha) of sweet sorghum Kawali higher than that of the varieties tested. The Kawali has a high potential to produce a biofuel because it had a highest fresh stem weight and juice content.
\end{abstract}

Key words : Sorghum, rubber, sweet sorghum, intercrops and land productivity.

\section{PENDAHULUAN}

Lahan di antara tanaman karet belum menghasilkan (TBM) merupakan lahan yang potensial untuk peningkatan produktivitas pertanian rakyat terpadu melalui tumpang sari pangan dengan komoditas perkebunan. Luasan lahan ini sangat potensial sebagai pengganti luasan yang menyusut dari lahan sawah. Secara produktivitas tidak sebanding, tetapi dari berbagai hasil penelitian, peningkatan produktivitas lahan ini sangat terbuka untuk dilakukan. Menurut Deptan (2010) luas areal perkebunan di Indonesia, khususnya karet, mencapai 3,3 juta ha, di mana $3 \%-4 \%$ dari luasan tersebut berada pada masa TBM yang berumur 1-3 tahun yang berpotensi untuk digunakan sebagai areal perluasan tanaman pangan. Menurut Fikriati et al. (2009) lahan perkebunan tersebut dapat dimanfaatkan secara intensif untuk usaha tani lainnya. Apabila penanaman pangan secara intercropping dengan memanfaatkan lahan di bawah tegakan tanaman perkebunan tersebut, khususnya karet, dilakukan maka diharapkan produktivitas pangan dalam negeri akan meningkat.

Tanaman sela di antara karet tidak mengganggu pertumbuhan lilit batang karet, bahkan pada banyak penelitian pertumbuhan lilit batang karet lebih baik pada sistem tanaman sela dibandingkan dengan penggunaan kacangan penutup tanah (Wibawa dan Rosyid, 1995). Pemeliharaan dan perawatan tanaman karet belum menghasilkan sangat berpengaruh terhadap produksi lateks tanaman. Pemberian pupuk untuk mensuplai kebutuhan hara tanaman, pemanfaatan lahan melalui penanaman tanaman sela juga merupakan hal yang sangat penting (Anwar, 2001). Penanaman tanaman yang berumur pendek di sela-sela tanaman berumur panjang, bertujuan menekan pertumbuhan gulma dengan cara menutupi areal yang biasa ditumbuhi gulma (Anwar, 2001; Syawal, 2010).

Keuntungan dari penanaman tanaman pangan sebagai tanaman sela karet, yaitu 1) tanaman sela dapat berfungsi sebagai tanaman penutup tanah, sehingga berfungsi untuk konservasi lahan karet, 2) efisiensi biaya usahatani dan tenaga kerja, karena biaya usahatani pemeliharaan tanaman karet dapat dilakukan bersama-sama dengan pemeliharaan tanaman sela, 3) meningkatkan pendapatan petani dan 4) petani dapat menyediakan kebutuhan pangan keluarganya secara swadaya, sehingga dapat menghemat kebutuhan pangan di daerah. Pola tanaman pangan sebagai tanaman sela karet seperti 
tumpang sari jagung + padi dan tumpang gilir padi gogo - kedelai dapat diusahakan sebagai tanaman sela karet yang menggunakan jarak tanam $6 \mathrm{~m} \times 3 \mathrm{~m}$ atau $7 \mathrm{~m} \times 3 \mathrm{~m}$ sampai dengan tanaman karet berumur dua atau tiga tahun (Rosyid et al., 2012). Di negara - negara lain juga seperti di India, Srilangka, Vietnam, Laos, Cina dan Pilipina menunjukkan bahwa menanam tanaman pangan dan palawija sebagai tanaman sela karet hanya dapat ditanam sampai dengan tanaman karet berumur dua atau tiga tahun. Pada saat ini dengan semakin menyempitnya pemilikan lahan, para petani cenderung menanam karet dengan jarak tanam yang lebih rapat, yaitu $4 \mathrm{~m}$ x $3 \mathrm{~m}, 5 \mathrm{~m} \times 2 \mathrm{~m}$, dan $3 \mathrm{~m} \times 3 \mathrm{~m}$. Pada kondisi seperti ini tanaman sela pangan hanya pada umur satu tahun (Rodrigo et al., 2004; Raintree, 2005; dan Xianhai et al., 2012).

Upaya untuk peningkatan produksi sorgum dapat dilaksanakan dengan memperluas areal penanaman, namun areal lahan yang tersedia sudah sangat terbatas dan jauh dari pemukiman. Pengembangan tanaman sorgum pada areal perkebunan karet rakyat sangat memungkinkan untuk dilaksanakan, yaitu dengan menanam sebagai tanaman sela karet. Hal ini sangat memungkinkan untuk dilaksanakan, karena pada usahatani karet di Indonesia rata-rata perluasan dan peremajaan karet setiap tahunnya sekitar 24700 ha (Ditjenbun, 2012). Sorgum adalah tanaman serelia yang toleran terhadap kekeringan. Potensi hasil sorgum bahkan lebih tinggi pada musim kemarau. Selain toleran kekeringan, sorgum juga dapat diratun dan mampu menghasilkan biji. Budidaya sorgum tidak berbeda dengan jagung, bahkan perawatannya lebih mudah. Rata-rata kebutuhan air bagi sorgum per musim tanam sekitar $4000 \mathrm{~m}^{3}$ sedangkan untuk jagung sekitar $8000 \mathrm{~m}^{3}$. Sebagai bahan pangan biji sorgum memiliki gizi yang memadai. Sorgum yang berkadar tannin tinggi dapat digunakan sebagai bahan baku obat. Sementara batang dan daunnya dapat dimanfaatkan sebagai pakan ternak. Sorgum juga dapat digunakan sebagai bahan baku etanol, bir, sirup, lem dan cat (FAO, 2002; Toure et al., 2004; Setyowati et al., 2005; Hoeman, 2007; dan Sihono, 2009).

Pusat Aplikasi Teknologi Isotop (PATIR), Badan Tenaga Nuklir Nasional (BATAN) telah melakukan penelitian sorgum yang difokuskan pada upaya perbaikan genetik tanaman untuk meningkatkan produksi dan kualitas sorgum sebagai sumber nahan pangan, pakan ternak dan bahan baku industri. Sejumlah varietas sorgum telah dihasilkan dan memiliki sifat agronomi yang lebih unggul dibanding varietas asal (Soeranto et al., 2003). Masalahnya adalah banyak varietas sorgum manis di Indonesia sehingga perlu dicari varietas sorgum yang sesuai untuk diusahakan sebagai tanaman sela karet. Tanaman sorgum diharapkan dapat meningkatkan pendapatan petani secara khusus dan secara umum mendukung program swasembada pangan melalui penyediaan sorgum di areal perkebunan karet. Penelitian ini dilakukan untuk mengetahui pengaruh tumpang sari karet + sorgum terhadap pertumbuhan tanaman karet belum menghasilkan, serta mempelajari beberapa parameter agronomi dan produksi sorgum manis sebagai tanaman sela karet.

\section{BAHAN DAN METODE}

Penelitian telah dilaksanakan di Kebun Percobaan Balai Penelitian Sembawa pada jenis tanah Podzolik Merah Kuning (PMK) dari bulan Juni sampai Oktober 2013. Lokasi penelitian dipilih pada areal kebun karet muda yang cukup seragam, berdasarkan pada jenis klon karet dan kondisi pertanaman. Percobaan ini merupakan percobaan faktor tunggal menggunakan rancangan acak kelompok (RAK) dengan tiga ulangan. Faktor perlakuannya adalah tiga varietas sorgum yaitu Pahat, Kawali dan Mandau ditanam secara acak dalam plot. Luas tiap plot percobaan adalah $500 \mathrm{~m}^{2}$ (populasi 50 tanaman karet/plot). Pada setiap satuan percobaan diambil tanaman karet dan sorgum sebagai tanaman contoh masing-masih 20 tanaman. Pengolahan tanah dilakukan pada tiap plot secara minimal (minimum tillage) dan pembersihan gulma. Jarak plot dari tanaman karet $1 \mathrm{~m}$, jarak antara plot $1 \mathrm{~m}$. Jarak tanam sorgum adalah $70 \times 15 \mathrm{~cm}$, ditanam $3-4$ biji per lubang.

Pada umur satu minggu setelah tanam (MST) dilakukan penyulaman, jika tanaman tidak tumbuh $80 \%$, penjarangan dilakukan saat tanaman berumur 3 MST, disisakan satu tanaman setiap lubang sehingga populasi/plot menjadi 177 tanaman. Bahan yang digunakan meliputi (1) benih dari 3 varietas sorgum yaitu Pahat, Kawali dan Mandau, (2) dolomit, 2 ton/ha diaplikasikan satu minggu sebelum tanam dengan tujuan untuk menaikan $\mathrm{pH}$ tanah, (3) pemupukan dilakukan dengan menggunakan $150 \mathrm{~kg}$ Urea/ha, $100 \mathrm{~kg}$ SP. 36/ha, dan $90 \mathrm{~kg} \mathrm{KCl/ha} \mathrm{diberikan} \mathrm{pada} \mathrm{saat}$ tanam. Pupuk Urea diberikan $1 / 3$ bagian saat tanam dan $2 / 3$ bagian setelah selesai penjarangan atau saat tanaman berumur 30 HST. Dosis pupuk yang digunakan berdasarkan rekomendasi dari Pusat Aplikasi 
Teknologi Isotop dan Radiasi (PATIR), Badan Tenaga Nuklir Nasional (BATAN) mengacu pada hasil penelitian di Kansas State University Agricultural Experiment Station and Cooperative Extention Service (1998), dan (4) untuk mencegah hama menyerang akar digunakan furadan dan untuk mencegah penyakit/hama daun digunakan Dithane M45.

Pengumpulan data primer tanaman karet dilakukan dengan cara metode simple random sampling dengan membandingkan tanaman karet pola tumpang sari sorgum dengan pola tumpang sari bibit batang bawah. Bahan tanam karet yang digunakan adalah bibit polibeg dua payung, yaitu klon IRR 118 dengan jarak tanam $6 \mathrm{~m} \times 3 \mathrm{~m}$ (populasi 550 pohon/ha), dan ukuran lubang tanam $60 \mathrm{~cm} x$ $60 \mathrm{~cm} \times 60 \mathrm{~cm}$. Pemupukan tanaman karet sesuai dengan rekomendasi analisis hara tanah dan daun. Parameter tanaman sorgum yang diamati adalah umur saat berbunga 50\% (hari), umur panen (hari), diameter batang $(\mathrm{cm})$, tinggi tanaman saat panen $(\mathrm{cm})$, berat batang segar (ton/ha), hasil nira (ton/ha), berat biji per malai (g), berat 100 biji (g), dan produksi biji (ton/ha). Parameter tanaman karet yang diamati adalah pertumbuhan lilit batang (cm) pada umur 4, 8, dan 12 bulan setelah tanam (BST). Pengukuran lilit batang pada umur 4 dan 8 bulan $10 \mathrm{~cm}$ dari pertautan okulasi (dpo), sedangkan pada umur 12 bulan $100 \mathrm{~cm}$ dpo.

Analisis kimia tanah sebelum olah tanah dan setelah panen sorgum dilakukan pada kedalaman $20 \mathrm{~cm}$. Analisis tanah dilakukan untuk $\mathrm{pH}, \mathrm{C}$-organik, $\mathrm{N}, \mathrm{P}_{2} \mathrm{O}_{5}, \mathrm{~K}_{2} \mathrm{O}$, nilai tukar kation $\mathrm{Ca}, \mathrm{Mg}$, dan kapasitas tukar kation (KTK). Kemasaman tanah $(\mathrm{pH})$ ditentukan dengan ekstrak 1:5 menggunakan $\mathrm{H}_{2} \mathrm{O}$ dan $\mathrm{KCl}$, C-organik ditentukan dengan metode kurmis, $\mathrm{N}$ ditentukan dengan metode Kjedahl,
$\mathrm{P}_{2} \mathrm{O}_{5}$ ditentukan dengan metode Bray II, $\mathrm{K}_{2} \mathrm{O}$ ditentukan dengan metode Morgan, Kation dan unsur hara mikro dengan metode Atomic Absorption Spectrometer (AAS), dan KTK dengan metode titrasi. Pengumpulan data iklim dengan AWS (Automatic Weather Stations).

Data pertumbuhan dan komponen hasil sorgum dianalisis dengan sidik ragam, jika berbeda nyata maka dilanjutkan dengan uji lanjut DMRT (Duncan Multiple Range Test) pada taraf $5 \%$ dengan program SAS 9.0. Data pengamatan pertumbuhan lilit batang tanaman karet dianalisis menggunakan uji t (paired samples test) dengan membandingkan pertumbuhan lilit batang tanaman karet pola tumpang sari sorgum dengan pola tumpang sari bibit batang bawah (Gomez and Gomez, 1995).

\section{HASIL DAN PEMBAHASAN}

\section{Agroekologi dan Air dalam Hubungannya dengan Penanaman Sorgum \\ Agroekosistem lokasi penelitian adalah} jenis tanah Podzolik Merah Kuning (PMK), dengan tekstur tanah termasuk dalam kelas tekstur lempung liat berpasir (Tabel 2). Tutupan lahan yang dominan pada daerah ini adalah karet. Rata-rata curah hujan musim tanam tahun 2013/2014 dilokasi penelitian adalah $3000 \mathrm{~mm} /$ tahun dengan curah hujan tertinggi terjadi pada bulan November - Mei (300-400 mm) dan bulan-bulan kering terjadi pada bulan Juni - September (100-200 mm) (Gambar 1). Rata-rata kelembaban udara sepanjang tahun $>80 \%$ dengan rata-rata suhu udara maksimum $32{ }^{\circ} \mathrm{C}$ dan minimum $23{ }^{\circ} \mathrm{C}$ (stasiun klimatologi Balai Penelitian Sembawa, Pusat Penelitian Karet, 2014).

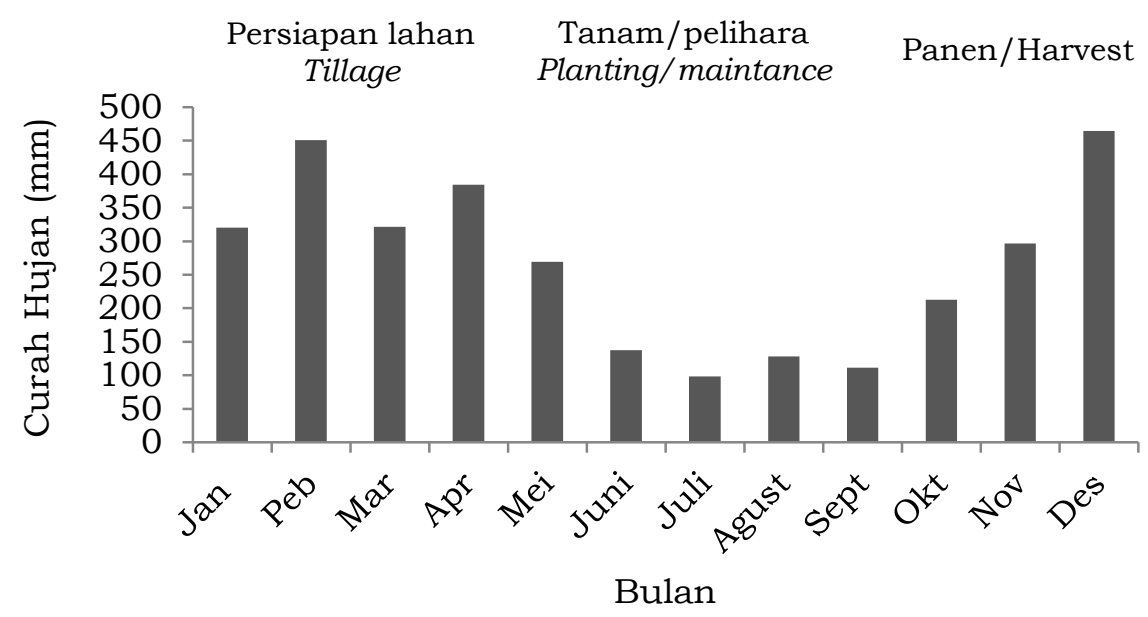

Gambar 1. Rata-rata curah hujan bulanan musim tanam tahun 2013/2014 di Stasiun Sembawa 
Berdasarkan tipe iklim, sebaran bulan basah dan bulan kering tersebut, maka kecukupan air tidak menjadi faktor pembatas bagi pengembangan sorgum manis sebagai tanaman sela karet di wilayah tersebut. Menurut Klasifikasi Oldeman et al. (1980) dan As-syakur (2009), lokasi penelitian termasuk dalam Tipe Iklim B-2, yaitu tipe iklim dengan jumlah bulan basah (bulan dengan curah hujan $>200 \mathrm{~mm}$ ) antara 7 - 9 bulan dan jumlah bulan kering (bulan dengan curah hujan $<100 \mathrm{~mm}$ ) antara 2-3 bulan. Menurut Tabri dan Zubachtirodin (2013), kriteria bulan kering 2,02,5 bulan dengan curah hujan $50-100 \mathrm{~mm}$ per bulan merupakan curah hujan yang ideal untuk keberhasilan produksi sorgum. Aqil dan Bunyamin (2013) menyatakan suhu optimum untuk pertumbuhan sorgum antara $21-35^{\circ} \mathrm{C}$ dan suhu minimum antara $15-18^{\circ} \mathrm{C}$.

Pola tanam sela sorgum diawal pertumbuhan memerlukan air untuk perkecambahan sampai tanaman berumur 30 hari stelah tanam (HST). Oleh karena itu, penanaman sorgum sebaiknya dimulai setelah musim hujan mulai stabil, yaitu pada pada bulan Mei (Gambar 1). Musim panen tergantung dari varietas yang digunakan. Umur panen sorgum sekitar berumur $3-3.5$ bulan. Dengan demikian periode saat tanam dan panen harus disesuaikan dengan karakteristik hujan setempat, sehingga produksinya mencapai tingkat optimal.

Ketersedian air sangat penting pada masa vegetatif dan pada masa pembungaan tanaman sorgum. Ketersediaan air menyebabkan fotosintesis di daun lebih efisien dan akan merangsang pembentukan bunga lebih banyak. Namun jika air tidak tersedia tersedia menyebabkan penyerbukan tidak terjadi dan bunga rontok. Menurut Aqil dan Bunyamin (2013), tanaman sorgum lebih toleran terhadap kekurangan air pada fase vegetatif dan pemasakan biji dibandingkan fase pembungaan dan pengisian biji. Kekurangan air pada fase vegetatif dan pemasakan biji hanya menurunkan hasil biji sebesar 15\%. Kekurangan air pada fase pembungaan dan pengisian biji menurunkan hasil biji sampai 50\%. Selanjutnya Irwan (2006) menyatakan bahwa pada suhu yang tinggi, air tersedia dan kelembaban udara yang rendah, maka radiasi matahari akan merangsang munculnya tunas bunga menjadi bunga.

\section{Respon Tumpang Sari Sorgum Terhadap Pertumbuhan Karet dan Produktivitas Lahan}

Lilit batang karet semua klon pada pola tumpang sari karet+sorgum lebih baik dibandingkan dengan pola tumpang sari bibit batang bawah. Secara statistik uji-t, pada umur 4 bulan pertumbuhan lilit batang karet semua klon pada pola tumpang sari karet+sorgum tidak berbeda nyata dibandingkan dengan pola tumpang sari bibit batang bawah. Pada umur 8 bulan hanya lilit batang karet klon BPM 109 yang tidak berbeda nyata. Pada umur 12 bulan pertumbuhan lilit batang karet semua klon berbeda nyata (Tabel 1). Hal ini menunjukkan bahwa masingmasing klon karet memiliki respon pertumbuhan yang berbeda dengan adanya tanaman sela sorgum.

Hasil penelitian ini menunjukkan bahwa adanya tanaman sorgum sebagai tanaman sela karet berpengaruh positif terhadap pertumbuhan tanaman karet. Bahkan dengan adanya pemeliharaan lahan yang baik melalui pemupukan $\mathrm{N}, \mathrm{P}, \mathrm{K}$, pengomposan sisa panen tanaman sorgum, pemeliharaan tanaman sorgum, penyiangan gulma, pengawasan dan pengendalian hama dan penyakit struktur tanah menjadi lebih gembur dan kaya unsur hara. Oleh karena itu, pertumbuhan tanaman karet pola tumpang sari sorgum menjadi lebih baik dan tumbuh lebih dari kondisi normal dibandingkan pertumbuhan tanaman karet pola tumpang sari bibit batang bawah. Hasil penelitian Rodrigo et al. (2005), menunjukkan bahwa pertumbuhan karet masa TBM dipengaruhi oleh adanya tanaman sela. Tanaman sela berpengaruh pada peningkatan pertumbuhan karet yang berkelanjutan, ketebalan kulit, hasil lateks, dan mempersingkat masa TBM dibandingkan dengan tanaman karet pola monokultur.

Tabel 1. Pertumbuhan lilit batang karet pada pola tanam sorgum sebagai tanaman sela

\begin{tabular}{ccccccc}
\hline \multirow{2}{*}{ Pola Tanaman Sela } & \multicolumn{7}{c}{$\begin{array}{c}\text { Lilit Batang Karet (cm) } \\
\text { Umur (Bulan) }\end{array}$} \\
\cline { 2 - 6 } & 4 & $\mathrm{P}$ & 8 & $\mathrm{P}$ & 12 & $\mathrm{P}$ \\
\hline IRR 118 + sorgum & 4,43 & \multirow{2}{*}{$0,097^{\text {tn }}$} & 8,16 & \multirow{2}{*}{$0,026^{*}$} & 12,11 & $0,021^{*}$ \\
\hline IRR 118 (monokultur) & 4,18 & 7,80 & & 11,21 & 11,66 \\
\hline Rata-rata & 4,31 & \multicolumn{7}{c}{7,98} & & \\
\hline
\end{tabular}

Keterangan): *) nyata pada $\mathrm{P}<0,05,{ }^{\prime *}$ ) nyata pada $\left.\mathrm{P}<0,01, \mathrm{tn}\right)$ tidak berbeda nyata dan (+) tumpang sari 
Pertumbuhan tanaman karet juga dipengaruhi oleh sistem pengolahan tanah pada saat pengolahan lahan untuk tanaman sorgum seperti pencangkulan, penggaruan, dan pembumbunan tanah. Hal ini menyebabkan terangkatnya lapisan bawah tanah sehingga tanah gembur dan pertumbuhan serta perkembangan akar tanaman karet dan sorgum lebih baik. Hasil penelitian Wibawa dan Rosyid (1995) menunjukkan bahwa perbaikan struktur tanah ultisol melalui pengolahan tanah dapat meningkatkan serapan unsur hara $\mathrm{N}$ dan $\mathrm{P}$ sehingga sistem perakaran menjadi lebih baik. Selanjutnya menurut Ar-riza (2001), tujuan utama dari pengolahan tanah adalah membentuk agregat yang stabil sehingga penanaman, perkecambahan, perkembangan akar, pergerakan air, dan udara akan lebih mudah dan bebas.

Tabel 2. Data analisis tanah sebelum tanam dan sesudah panen sorgum

\begin{tabular}{lcc}
\hline $\begin{array}{l}\text { Peubah Analisis } \\
\text { Analysis Variables }\end{array}$ & $\begin{array}{c}\text { Sebelum Tanam } \\
\text { Before Planting }\end{array}$ & $\begin{array}{c}\text { Saat Panen } \\
\text { After Harvest }\end{array}$ \\
\hline $\mathrm{Ph}$ & $4,37 \mathrm{sm}$ & $5,04 \mathrm{~m}$ \\
$\mathrm{C}$ - Organik (\%) & $1,83 \mathrm{r}$ & $3,19 \mathrm{t}$ \\
$\mathrm{N}$-total (\%) & $0,13 \mathrm{r}$ & $0,20 \mathrm{sd}$ \\
$\mathrm{P}_{2} \mathrm{O}_{5}(\mathrm{Bray}$ II) (ppm) & $4,77 \mathrm{sr}$ & $5,19 \mathrm{r}$ \\
$\mathrm{K} 2 \mathrm{O}($ Morgan) (me/100 gr) & $0,02 \mathrm{sr}$ & $0,05 \mathrm{sr}$ \\
$\mathrm{Ca}$ (me/100 gr) & $0,11 \mathrm{sr}$ & $0,20 \mathrm{sr}$ \\
$\mathrm{Mg}(\mathrm{me} / 100 \mathrm{gr})$ & $0,02 \mathrm{sr}$ & $0,12 \mathrm{r}$ \\
$\mathrm{KTK}(\mathrm{me} / 100 \mathrm{gr})$ & $8,9 \mathrm{sr}$ & $10,74 \mathrm{r}$ \\
Kejenuhan Al/Al Saturated (\%) & $50,60 \mathrm{st}$ & \\
\hline Keterangan: r rendah; sr = sangat rendah; sd = sedang; t = tinggi; st = sangat tinggi; m = masam; sm = sangat
\end{tabular}

Hasil analisis tanah di lokasi penelitian sebelum tanam menunjukkan bahwa nilai $\mathrm{pH}$, kapasitas tukar kation (KTK), N, P, K, Ca, dan $\mathrm{Mg}$ sangat rendah. Namun dengan adanya sorgum sebagai tanaman sela karet berpengaruh positif terhadap peningkatan produktivitas lahan. Kondisi $\mathrm{pH}$ tanah meningkat dari sangat masam menjadi masam, C-Organik meningkat dari rendah menjadi tinggi, $\mathrm{N}$-total cenderung meningkat dari rendah menjadi sedang, KTK dan kation $\mathrm{N}, \mathrm{P}, \mathrm{K}, \mathrm{Ca}, \mathrm{Mg}$ meningkat dari sangat rendah menjadi rendah. Namun tanah tersebut memiliki kejenuhan alumunium (Al) yang tinggi $50.60 \%$ (Tabel 2). Kondisi tanah yang demikian tergolong lahan bermasalah dan mempunyai tingkat kesuburan yang rendah. Oleh karena itu, tanah tersebut membutuhkan penambahan kapur dan bahan organik untuk peningkatan produktivitas lahan, pertumbuhan, dan produksi tanaman karet dan sorgum. Menurut Santoso (2006), ketersediaan hara N, $\mathrm{P}, \mathrm{K}, \mathrm{Ca}$, dan $\mathrm{Mg}$ dipengaruhi oleh $\mathrm{pH}$ tanah dan jumlah Al bebas dalam tanah. Kandungan Al tinggi di dalam tanah menyebabkan kationkation terutama $P$ terikat menjadi Al-P yang sulit untuk dilepas, sehingga $P$ tidak tersedia bagi tanaman.

\section{Pembungaan 50\%, Umur Panen, dan Tinggi Tanaman Sorgum}

Seleksi sorgum untuk umur berbunga harus lebih mendapat perhatian mengingat korelasi yang nyata dengan umur panen. Korelasi yang nyata ini menguntungkan dalam mencari tanaman sorgum yang berumur genjah. Namun demikian ada kecenderungan untuk berkurangnya hasil dan bobot biji per malai dengan semakin cepatnya umur panen tanaman. Umur berbunga yang cepat berhubungan dengan pengurangan jumlah buku dan jumlah daun tanaman sorgum yang akan mempengaruhi laju fotosintesis tanaman (Anas et al., 2007).

Data pengamatan pembungaan yang diukur dari 50\% tanaman berbunga dan umur panen disajikan dalam Tabel 3. Data dalam Tabel 3 menunjukkan bahwa tanaman sorgum yang tercepat berbunga adalah varietas Kawali $(63,67$ hari) sedangkan terlama adalah varietas Pahat (68,66 hari). Varietas Kawali lebih cepat berbunga, sehingga umur panen lebih cepat $(102,67$ hari) dan mampu berproduksi biji tinggi (2,69 ton/ha) dari semua varietas yang diuji. Hal ini menunjukkan bahwa varietas Kawali mampu melakukan proses fotosintesis optimal yang merupakan produsen fotosintat utama bagi tanaman, sehingga dapat dijadikan sebagai indikator pertumbuhan terutama untuk proses pembentukan biomassa tanaman.

Tanaman sorgum manis mengalami peningkatan tinggi tanaman seiring dengan peningkatan umur dan maksimal terjadi sebelum memasuki fase generatif. Tabel 3 menunjukkan bahwa terdapat pengaruh varietas sorgum terhadap tinggi tanaman. Dari 
3 varietas yang diuji, yang memiliki tinggi tanaman tertinggi adalah Kawali $(148,00 \mathrm{~cm})$ dan terpendek adalah Mandau $(144,40 \mathrm{~cm})$, dan tidak berbeda nyata dengan Pahat dan Kawali.

Tabel 3. Umur bunga, umur panen, dan tinggi tanaman berbagai genotipe sorgum sebagai tanaman sela karet

\begin{tabular}{llll}
\hline Varietas & Umur Bunga (hari) & Umur Panen (Hari) & Tinggi Tanaman (cm) \\
\hline Pahat & $68,66^{\mathrm{a}}$ & $105,67^{\mathrm{a}}$ & $146,37^{\mathrm{ab}}$ \\
Kawali & $63,67^{\mathrm{c}}$ & $102,67^{\mathrm{c}}$ & $148,00^{\mathrm{a}}$ \\
Mandau & $66,67^{\mathrm{ab}}$ & $104,33^{\mathrm{ab}}$ & $144,40^{\mathrm{c}}$ \\
\hline Rata-rata & 66,33 & 104,22 & 146,26 \\
\hline KK $(\%)$ & 4,06 & 1,32 & 4,02 \\
\hline
\end{tabular}

Keterangan: Nilai yang diikuti oleh huruf yang berbeda pada kolom yang sama berbeda nyata pada uji jarak berganda DMRT pada taraf $5 \%$

Varietas yang memiliki batang tinggi tidak berkorelasi positif dengan produksi per hektar, seperti varietas Mandau walaupun berbatang pendek memiliki produksi biji kering tinggi yaitu 2.05 ton/ha tidak berbeda nyata dengan varietas Kawali. Hal ini disebabkan oleh genotipe yang berbatang pendek lebih efisien dalam pemanfaatan sinar matahari dan juga memudahkan pemanenan serta menghindari rentannya tanaman terhadap angin.

\section{Diameter batang, Biomassa Batang, Kandungan Nira, dan Hasil Nira}

Tanaman sorgum berdiameter batang lebih besar dimungkinkan pertumbuhannya lebih baik dan dapat menopang tanaman lebih kuat sehingga tidak mudah roboh. Agar tanaman dapat menjalankan fungsi fisiologisnya dengan baik, batang tanaman harus dapat berdiri dengan tegak. Data pengamatan diameter tanaman sorgum disajikan dalam Tabel 4. Dari 3 varietas yang diuji rata-rata diameter batang terbesar adalah varietas Kawali $(2,23 \mathrm{~cm})$. Hal ini menyebabkan varietas Kawali memiliki berat batang segar yang relatif tinggi $(37,11$ ton/ha), memiliki hasil nira yang relatif tinggi $(1,80$ ton/ha). Adanya suplai asimilat dari source (daun) ke sink (batang) berlangsung lama dan akhirnya dapat meningkatkan biomassa batang, kandungan nira batang dan pembentukan biji. Menurut Rahayu et al. (2012), pertumbuhan akan mengakibatkan perubahan ukuran tanaman menjadi semakin besar dan menentukan hasil tanaman. Diameter batang tanaman sorgum manis mengalami peningkatan seiring dengan peningkatan umur. Selain itu, juga dapat dilihat dari besarnya brangkasan segar dan kering tanaman. Berat brangkasan segar menggambarkan tingkat efektivitas penyerapan air oleh tanaman, sedangkan brangkasan kering mencerminkan bagaimana proses fotosintesis berlangsung.

Tabel 4. Diameter batang, berat batang, dan kandungan nira berbagai genotipe sorgum sebagai tanaman sela karet

\begin{tabular}{llll}
\hline Varietas & Diameter Batang (cm) & $\begin{array}{c}\text { Berat Batang Segar } \\
\text { (ton/ha) }\end{array}$ & Hasil Nira (ton/ha) \\
\hline Pahat & $1,92^{\mathrm{c}}$ & $28,86^{\mathrm{c}}$ & $1,20^{\mathrm{b}}$ \\
Kawali & $2,23^{\mathrm{a}}$ & $37,11^{\mathrm{a}}$ & $1,80^{\mathrm{a}}$ \\
Mandau & $2,05^{\mathrm{ab}}$ & $30,22^{\mathrm{bc}}$ & $1,50^{\mathrm{ab}}$ \\
\hline Rata-rata & 2,07 & 32,06 & 1,50 \\
\hline KK (\%) & 17,41 & 19,64 & 12,96 \\
\hline Keterangan: Nilai yang diikuti oleh huruf yang berbeda pada kolom yang sama berbeda nyata pada uji jarak
\end{tabular}

Kualitas dan kuantitas hasil nira sorgum ditentukan oleh ketepatan waktu tanam dan panen. Panen batang, daun, dan biji sorgum untuk bahan pakan ternak dilakukan pada umur 75-80 HST. Panen batang sorgum untuk diperas niranya dilakukan pada umur 90 - 105 HST (Sukmadi, 2010), dan untuk pembuatan bioetanol terbaik pada umur panen 80 hari
(Suparti et al., 2012). Pada penelitian ini, panen batang sorgum untuk diperas niranya dilakukan pada umur 102 - 104 HST (Tabel 3). Menurut Warsa (2006), nira sorgum merupakan cairan yang diperoleh dari pengepresan batang sorgum manis. Nira sorgum dapat dimanfaatkan untuk pembuatan etanol karena komposisinya hampir sama 
dengan nira tebu. Selanjutnya Rahayu et al. (2011) menyatakan bahwa kandungan nira dalam batang sorgum manis dipengaruhi oleh jenis sorgum, iklim, umur sorgum, dan cara pemeliharaan yang meliputi pemberian pupuk dan pengairan. Pada tanaman sorgum manis yang telah memasuki fase generatif kadar kemanisan akan berkurang diduga karena timbunan sukrosa dialihkan untuk pembentukan biji.

\section{Berat Biji per Malai, Berat 100 biji, dan Hasil Biji}

Hasil yang dapat diperoleh dari tanaman sorgum manis juga dapat berupa biji sebagai bahan pangan, pakan ternak maupun bioetanol. Biji merupakan cadangan makanan serta dapat dipergunakan sebagai benih yang dapat dijadikan bahan tanam. Proses pembentukan biji dipengaruhi oleh faktor lingkungan maupun genetik. Berat biji per malai dan berat 100 biji merupakan salah satu parameter yang berkaitan dengan produksi suatu tanaman. Apabila jumlah biji pertanaman sama tetapi memiliki berat 100 biji lebih tinggi maka hasil yang diperoleh akan lebih besar (Rahayu et al., 2011).

Tabel 5. Berat biji, berat 100 biji, dan hasil biji berbagai getotipe sorgum sebagai tanaman sela karet

\begin{tabular}{lccc}
\hline Varietas & \multirow{2}{*}{ Berat Biji per Malai (g) } & Berat 100 Biji (g) & Hasil Biji (ton/ha) \\
\hline Pahat & $23,84^{\mathrm{c}}$ & $2,76^{\mathrm{a}}$ & $1,21^{\mathrm{b}}$ \\
Kawali & $40,54^{\mathrm{a}}$ & $2,38^{\mathrm{a}}$ & $2,69^{\mathrm{a}}$ \\
Mandau & $34,94^{\mathrm{b}}$ & $2,68^{\mathrm{a}}$ & $2,05^{\mathrm{ab}}$ \\
\hline Rata-rata & 33,11 & 2,61 & 1,98 \\
\hline KK (\%) & 16,62 & 5,98 & 20,35 \\
\hline
\end{tabular}

Keterangan: Nilai yang diikuti oleh huruf yang berbeda pada kolom yang sama berbeda nyata pada uji jarak berganda DMRT pada taraf $5 \%$

Berat 100 butir biji tidak berkorelasi positif dengan produktivitas per hektar, karena biji yang besar terkadang memiliki jumlah biji per malai sedikit. Hal ini tampak pada varietas Pahat memiliki ukuran biji yang besar sehingga bobot 100 biji tinggi yaitu 2,76 g, namun memiliki produksi biji per hektar yang rendah, yaitu varietas pahat (1.21 ton/ha). Sedangkan varietas Kawali dan Mandau memiliki ukuran biji yang kecil sehingga bobot 100 biji rendah, masing-masing yaitu $2.38 \mathrm{~g}$ dan $2.68 \mathrm{~g}$, namun mampu memproduksi biji kering lebih tinggi yaitu varietas Kawali (2.69 ton/ha) dan Mandau (2.05 ton/ha). Hal ini karena ukuran biji yang kecil pada varietas Kawali dan Mandau diimbangi dengan berat biji per malai yang lebih berat, sehingga varietas Kawali dan Kawali berproduksi lebih tinggi (Tabel 5).

\section{KESIMPULAN DAN SARAN}

Hasil penelitian menunjukkan bahwa sorgum sebagai tanaman sela memiliki efek positif terhadap pertumbuhan tanaman karet klon IRR 118. Hasil uji adaptasi sorgum manis menunjukkan bahwa varietas Kawali memiliki berat batang segar $(37,11$ ton/ha), hasil nira (1,80 ton/ha) dan hasil biji (2.69 ton/ha) yang tertinggi sehingga sangat potensi untuk dikembangkan sebagai bahan baku biofuel. Penampilan ketiga varietas sorgum, menunjukkan variasi sifat agronomi yang berbeda dan memberikan respon yang baik terhadap pertumbuhan dan hasil sehingga dapat dikembangkan sebagai tanaman sela karet. Diperlukan penelitian uji multilokasi dan multimusim untuk melihat penampilan sifat agronomi galur mutan sorgum yang lebih adaptif pada areal perkebunan karet.

\section{UCAPAN TERIMA KASIH}

Ucapan terimakasih kepada Ir. M. Jahidin Rosyid, MS sebagai peneliti utama yang telah memberikan masukan dan saran dalam penulisan makalah ini. Selain itu, penulis juga menyampaikan terima kasih kepada Oktalisa Yuna, AMd sebagai teknisi yang membantu pengamatan di lapangan.

\section{DAFTAR PUSTAKA}

Agustina, K., D. Sopandie, Trrikoesoemaningtyas dan D. Wirnas. 2010. Tanggap Fisiologi Akar Sorgum (Sorghum bicolor L. Moench) terhadap Cekaman Aluminium dan Defisiensi Fosfor di dalam Rhizotron. J. Agron. Indonesia, 38 (2) : 88 - 94.

Anas, Sumadi dan A.W. Irwan. 2007. Variabilitas Genetik dan Heritabilitas Beberapa Karakter Penting 19 Genotipe Elite Sorgum (Sorghum Bicolor (L) Moench) pada Pertanaman Musim Kering. Prosiding Simposium Tanaman Pangan. Seminar dan Kongres IX PERAGI. Bandung 17-18 Maret. Hal. 167-172. 
Anwar, K. 2001. Manajemen dan Teknologi Budidaya Karet. Pusat Penelitian Karet Medan. 24 hal.

Aqil, M dan Z. Bunyamin. 2013. Optimalisasi Pengelolaan Agroklimat Pertanaman Sorgum. Seminar Nasional Serealia, 2013. Balai Penelitian Tanaman Serealia. p. 371-379.

Ar-riza, I.D. Nazemi dan M. Alwi. 2001. Peranan Glifosat Dalam Pengendalian Gulma dan Suksesi Gulma pada Pertanaman Padi Intercrop dengan Tanman Karet di Lahan Kering Masam. Prosiding Konferensi Nasional XV, Himpunan IImu Gulma Indonesia. Suroto, D., A. Yunus, E. Purwanto, Wartoyo, dan Supriyono (ed), Surakarta, 17-19 Juli. hal. 496-503.

As-syakur, A.R. 2009. Evaluasi Zona Agroklimat Dari Klasifikasi SchimidtFerguson Menggunakan Aplikasi Sistem Informasi Geografi (SIG). Jurnal Pijar MIPA. 3(1):17-22.

Departemen Pertanian. 2010. Basis Data Pertanian. http://database.deptan.go.id. [9 Juli 2014].

Ditjenbun. 2012. Statistik Perkebunan Indonesia: Karet 2009-2012. Direktorat Jenderal Perkebunan, Jakarta. 52 hal.

Fikriati, M., Trikoesoemaningtyas dan Desta. W. 2009. Uji Daya Hasil Lanjutan Kedelai (Glycine max L.) Toleran Naungan di Bawah Tegakan Karet Rakyat di Kabupaen Sarolangun, Jambi. Makalah Seminar. Departemen Agronomi dan Hotikultura. Institut Pertanian Bogor. Bogor. 68 hal.

Food and Agricultural Organization. 2002. FAOSTAT Agricultural Database 2002. http://faostat.fao.org/faostat/.

Gomez, K.A and A.A. Gomez. 1995. Prosedur Statistik untuk Penelitian Pertanian. Terjemahan dari: Statistical Procedures for Agricultural Research. Penerjemah: E. Sjamsudin dan Baharsjah. Penerbit Universitas Indonesia. Jakarta. 698 hal.

Hoeman, S. 2007. Peluang dan Potensi Pengembangan Sorgum Manis. Makalah pada workshop. Peluang dan Tantangan Sorgum Manis sebagai Bahan Baku Bioetanol. Dirjen Perkebunan, Departemen Pertanian, Jakarta.

Irwan, A.W. 2006. Budidaya Tanaman Kedelai (Glycine max (I.) Merrill). Jurusan Budidaya Pertanian Faperta. Unpad. Jatinangor. 40 hal.

Kansas State University. 1998. Grain Sorghum Production Handbook. Kansas State University Agricultural Experiment
Station and Cooperative Extension Service, Manhattan, Kansas, May 1998. https://www.bookstore.ksre.ksu.edu/pub s/c687.pdf.

Oldeman. L., R. Irsal dan L. Muljadi. 1980. Agro-climatic Map of Sumatra Scale 1:3.000.000. Centre Research Institute for Agriculture. Bogor. 35 hal.

Rodrigo, V.H.L., T.U.K. Silva dan E.S. Munasinghe. 2004. Improving the Spatial Arrangement of Planting Rubber (Hevea brasiliensis Muell. Arg.) for Long-term Intercropping. Field Crops Research, 89(2): 327-335.

Rahayu, M., Samanhudi, \& Wartoyo. 2012. Uji Adaptasi Beberapa Varietas Sorgum Manis di Lahan Kering Wilayah Jawa Tengah dan Jawa Timur. Jurnal IImu Pertanian Fakultas Pertanian Universitas Sebelas Maret, 27 (1) 1-10.

Raintree, J. 2005. Intercropping with Rubber for Risk Management. In: the National University of Laos, National Agriculture and Forestry Research Institute and National Agriculture and Forestry Extension Service. Improving Livelihoods in the Lao PDR. Volume 2: Options and Opportunities. Vientiane, Lao PDR. pp. 41-46.

Rodrigo, V.H.L., C.M. Stirling, T.U.K. Silva, dan P.D. Pathirana. 2005. The Growth and Yield of Rubber at Maturity is Improved by Intercropping with Banana During The Early Stage of Rubber Cultivation. Field Crops Research, 91 (1): 23-33.

Rosyid, M.J., G. Wibawa dan A. Gunawan. 2012. Pola Usahatani Karet. Saptabina.Usahatani Karet. Balai Penelitian Sembawa. Pusat Penelitian Karet (eds) ke- 6. Palembang. 126 hal.

Santoso, B. 2006. Pemberdayaan Lahan Podsolik Merah Kuning dengan Tanaman Rosela (Hibiscus sabdariffa L.) di Kalimantan Selatan. J. Perspektif 5(1):1-12.

Setyowati, M., Hadiatmi, dan Sutoro. 2005. Evaluasi Pertumbuhan dan Hasil Plasma Nutfah Sorgum (Sorghum vulgare (L.) Moench.) dari Tanaman Induk dan Ratoon. Balai Besar Penelitian dan Pengembangan Bioteknologi dan Sumberdaya Genetik Pertanian, Bogor. Buletin Plasma Nutfah. 11(2): 41-49.

Sihono. 2009. Penampilan Sifat Agronomi Galur Mutan Sorgum (Sorghum bicolor (L) Moench) di Kabupaten Bogor. Jurnal Ilmiah Aplikasi Isotop dan Radiasi. Pusat Aplikasi Teknologi Isotop dan Radiasi 
Badan Tenaga Nuklir Nasional. Jakarta. 5(1): 31-42.

Soeranto, H., T.M. Nakanishi, dan M.T. Razak. 2003. Obtaining Induced Mutations of Drought Tolerance in Sorghum. Journal Radioisotopes, The Japan Radioisotopes. 52(1):15-21.

Sukmadi, B. 2010. Difusi Pemanfaatan Pupuk Organik, Pupuk Hayati dan Pestisida Hayati pada Budidaya Sorgum Manis (Sorghum bicolor L.) di Kabupaten Lampung Tengah. Balai Pengkajian Bioteknologi Deputi Bidang Teknologi Agroindustri dan Bioteknologi Badan Pengkajian dan Penenerapan Teknologi, Jakarta.

Suparti, A. Asngad dan Chalimah. 2012. Uji Kualitas Dan Kuantitas Produksi Bioethanol Batang Tanaman Sweet Sorghum Berbagai Varietas Skala Laboratorium. Laporan Hasil Penelitian Hibah Kompetitif Tahun I. Universitas Muhammadiyah Surakarta. 39 hal.

Syawal, Y. 2010. Pergeseran gulma pada tanaman pepaya (Carica papaya) yang diberi pupuk organik dan anorganik. Jurnal Agroteknologi. 2(2):34-38.
Tabri, F. dan Zubachtirodin. 2013. Budi Daya Tanaman Sorgum. Hal. 175-188. Dalam Sumarno, D.S. Damardjati, M. Syam, dan Hermanto (Eds). Inovasi Teknologi dan Pengembangan Sorgum. Badan Penelitian dan Pengembangan Pertanian. Jakarta :IAARD Press. 291 hal.

Toure, A., F.W. Rattunde, E. Weltzien. 2004. Guinea Sorghum Hybrids: Bringing the Benefits of Hybrid Technology to A Staple Crop of Sub-Saharan Africa. IER-ICRISAT.

Warsa, I.W. 2006. Kajian Pengaruh Fouling pada Pemurnian Nira Tebu. Jurnal Teknik Kimia, 1(1):22-25.

Wibawa, G. dan M.J. Rosyid. 1995. Peningkatan Produktivitas Padi Sebagai Tanaman Sela Karet. Warta Perkaretan, 14(1): 40-46.

Xianhai, Z., Mingdao, C., and Weifu, L. 2012. Improving Planting Pattern for Intercropping in The Whole Production Span of Rubber Tree. African Journal of Biotechnology, 11(34): 8484-8490. 
Pengaruh Tanaman Sela Sorgum Manis Terhadap Pertumbuhan Tanaman Karet (Sahuri) 